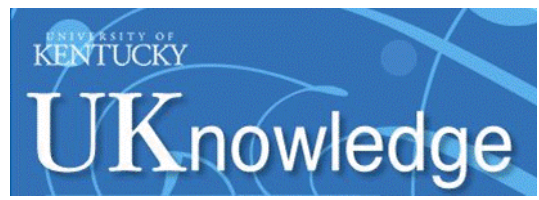

University of Kentucky

UKnowledge

$12-2015$

\title{
Prey Size and Dietary Niche of Rafinesque's Big-Eared Bat (Corynorhinus rafinesquii)
}

\author{
Luke E. Dodd \\ Eastern Kentucky University \\ Michael J. Lacki \\ University of Kentucky, mike.lacki@uky.edu \\ Joseph S. Johnson \\ Bucknell University \\ Lynne K. Rieske \\ University of Kentucky, lynne.rieske-kinney@uky.edu
}

Follow this and additional works at: https://uknowledge.uky.edu/forestry_facpub

Part of the Forest Sciences Commons

Right click to open a feedback form in a new tab to let us know how this document benefits you.

\section{Repository Citation}

Dodd, Luke E.; Lacki, Michael J.; Johnson, Joseph S.; and Rieske, Lynne K., "Prey Size and Dietary Niche of Rafinesque's Big-Eared Bat (Corynorhinus rafinesquii)" (2015). Forestry and Natural Resources Faculty Publications. 8.

https://uknowledge.uky.edu/forestry_facpub/8

This Article is brought to you for free and open access by the Forestry and Natural Resources at UKnowledge. It has been accepted for inclusion in Forestry and Natural Resources Faculty Publications by an authorized administrator of UKnowledge. For more information, please contact UKnowledge@lsv.uky.edu. 
Prey Size and Dietary Niche of Rafinesque's Big-Eared Bat (Corynorhinus rafinesquii)

Digital Object Identifier (DOI)

https://doi.org/10.1656/058.014.0412

Notes/Citation Information

Published by Southeastern Naturalist,v. 14, no. 4, p. 685-696.

The publisher, Eagle Hill Institute reserves the copyright to all its publications. Any reproduction, other than for an individual's own personal and private use, or distribution of journal content is prohibited without written permission from Eagle Hill Institute. 


\title{
Prey Size and Dietary Niche of Rafinesque's Big-Eared Bat (Corynorhinus rafinesquii)
}

\author{
Luke E. Dodd ${ }^{1, *}$, Michael J. Lacki², Joseph S. Johnson ${ }^{3}$, and Lynne K. Rieske ${ }^{4}$
}

\begin{abstract}
Bats in the genus Corynorhinus possess a suite of morphological characters that permit them to effectively use both gleaning and aerial-hawking foraging strategies to capture Lepidoptera. Consequently, they occupy a specialized feeding niche within North American bat assemblages and are of particular interest for dietary studies. We collected fecal pellets from a colony of $C$. rafinesquii (Rafinesque's Big-Eared Bat) at Mammoth Cave National Park during August-October 2011 and amplified cytochrome-c oxidase subunit 1 fragments of prey from these pellets. We used the Barcode of Life Database to identify prey, and evaluated the size of prey species based on published values. The mean wingspan of prey we recorded from our samples was smaller than average values reported for Rafinesque's Big-Eared Bat using traditional methods $(P \leq 0.01)$, suggesting that surveys of culled insect parts beneath roosting sites may lead to biased estimates of the size and breadth of prey species eaten by gleaning bats. Mean wingspan of lepidopteran prey consumed by Rafinesque's Big-Eared Bat in our study was larger $(P \leq 0.01)$ than values reported for the Myotis septentrionalis (Northern Long-Eared Bat), which is a smaller, sympatric gleaner in eastern North America. Further, comparisons of our diet data with abundance of prey suggest macrolepidopteran taxa are consistently consumed by Rafinesque's Big-Eared Bat to greater degree than microlepidotera. Our findings suggest that North American Corynorhinus consume a wider range of sizes and species of Lepidoptera than previously reported in studies based solely on identification of culled prey-wings beneath feeding roosts.
\end{abstract}

\section{Introduction}

Bats in the genus Corynorhinus (Vespertilionidae) are among the best examples to demonstrate dietary specialization found within diverse assemblages of insectivorous bats. Members of this genus and other vespertilionid species within the plecotine tribe possess adaptations that permit them to glean prey from surfaces in structurally complex environments (Lacki et al. 2007). The diets of these bats are well studied and, in contrast to many insectivorous bat species, use of traditional identification methods has permitted high-resolution identification of prey (Lacki and Dodd 2011). These dietary studies are aided by the bats' habit of capturing prey and returning to a roost for feeding. While at feeding roosts, Corynorhinus typically consume the soft portions of prey and discard the remnant wings. Although these remnants provide diagnostic characteristics that permit the identification of prey to the species level, the high-resolution dietary patterns generated from these samples

\footnotetext{
${ }^{1}$ Department of Biological Sciences, Eastern Kentucky University, Richmond, KY 40475. ${ }^{2}$ Department of Forestry, University of Kentucky, Lexington, KY 40546. ${ }^{3}$ Department of Biology, Bucknell University, Lewisburg, PA 17837. ${ }^{4}$ Department of Entomology, University of Kentucky, Lexington, KY 40546. 'Corresponding author - luke.dodd@eku.edu.
}

Manuscript Editor: John Kilgo 
are not without limitations or potential bias. For example, although previous studies indicated that both New and Old World plecotine bats consume larger-sized Lepidoptera (Alberdi et al. 2012, Lacki and Dodd 2011), it remains unclear whether historical methods resulted in a complete picture of the dietary breadth of these bats (i.e., dissection and morphological identification of gut contents or fecal pellets). Some researchers have postulated that Corynorhinus also capture smaller prey that are consumed in flight or in their entirety at the feeding roost (Burford and Lacki 1998, Sample and Whitmore 1993). Thus, the application of DNA-based methods can be used to investigate hypotheses regarding the feeding behavior of these bats (e.g., gleaning versus aerial hawking, location of prey consumption), and may also elucidate potential gaps in our knowledge regarding dietary breadth and prey size.

To date there has been no molecular investigation of the diet of any Corynorhinus species. However, there is an emerging body of data for Old World plecotine species that provide a foundation for comparison with North American species. Razgour et al. (2011) investigated overlap in the dietary niches of Plecotus auritus L. (Brown Long-Eared Bat) and Plecotus austriacus J. Fischer (Gray Long-Eared Bat) and found that they ate many of the same prey species, leading the authors to infer little dietary differentiation between these 2 bat species. The authors concluded that differences in the host-plant affinities of prey might result in variation in occurrence of prey and, subsequently, in the spatiotemporal separation of foraging activity between these sympatric species. More recently, Alberdi et al. (2012) documented the diet of Plecotus macrobullaris Kuzyakin (Mountain Long-Eared Bat) using molecular techniques. Their findings indicated that this rare bat consumes lepidopteran prey similar in size to those documented at feeding roosts of Corynorhinus in eastern North America (Lacki and Dodd 2011). Because of the need for a refined understanding of the prey consumed by these specialist insectivores, we sought to molecularly delineate the diet of Corynorhinus rafinesquii (Lesson) (Rafinesque's Big-Eared Bat), the most wide-ranging Corynorhinus in eastern North America (Bat Conservation International and the Southeastern Bat Diversity Network 2013).

We investigated whether the size of Lepidoptera identified using a DNA-based method differed from the size of known records of prey of Rafinesque's Big-Eared Bat and its congeners (Lacki and Dodd 2011), and hypothesized that past assessments for Rafineque's Big-Eared Bat are likely incomplete and under-represent the size-range of prey consumed by this predator. Secondly, we compared the size of Lepidoptera consumed by Rafineque's Big-Eared Bat in our study to the size of prey reported for Myotis septentrionalis (Trouessart) (Northern Long-Eared Bat), which is a co-occurring gleaning species (Caceres and Barclay 2000, Faure et al. 1993, Jones 1977). An established framework for prey selection of insectivorous bats predicts that larger bats eat larger prey relative to smaller bats, due to ease in prey handling and inherent differences in detection of prey resulting from echolocation characteristics (Barclay and Brigham 1991, Bogdanowicz et al. 1998, Freeman 1981). Following this paradigm, we hypothesized that Rafinesque's Big-Eared Bat would consume larger Lepidoptera than reported for the Northern Long-Eared Bat 
because the Northern Long-Eared Bat is smaller in size than Rafinesque's BigEared Bat (Barbour and Davis 1969). Lastly, we evaluated the lepidopteran prey consumed by Rafinesque's Big-Eared Bat in the context of lepidopteran prey abundance. Assuming Rafinesque's Big-Eared Bat does not select prey on the basis of size, we hypothesized that the consumption patterns of this predator would broadly follow the abundance patterns of Lepidoptera in habitats where these bats forage.

\section{Field-site Description}

We conducted our field work at Mammoth Cave National Park (MCNP; $\left.37.2072^{\circ} \mathrm{N}, 86.1319^{\circ} \mathrm{W}\right)$. This park encompasses 23,000 ha in Barren, Hart, and Edmonson counties and is positioned at the edge of the Crawford-Mammoth Cave Uplands of the Interior Plateau of Kentucky (Woods et al. 2002). The area is primarily forested and is dissected by numerous small drainages that create a topographically diverse landscape. Forest cover consists of Quercus (oak)-Carya (hickory) and western mixed mesophytic forests (Braun 1950). During summer, Rafinesque's Big-Eared Bat roosts in hollow trees, sandstone outcrops, caves, and abandoned human-made structures (Johnson et al. 2012). Numerous caves occur at MCNP, and this location possesses one of the largest known winter concentrations of Rafinesque's Big-Eared Bat (Bayless et al. 2011).

\section{Methods}

We collected fecal pellets beneath a colony of Rafinesque's Big-Eared Bat during late summer 2011. This roost was in the rafters of an equipment barn. Bats were found at this location throughout the maternity season of 2011 and were known to use this location as a maternity roost in past years (R. Toomey, US National Park Service, Mammoth Cave, KY, pers. comm.). For a single sampling interval, we entered the roost location at night after nearly all bats had left to forage $(\sim 1-1.5 \mathrm{hrs}$ after sunset). We placed a plastic tarpaulin $(2.7 \mathrm{~m} \times 3.7 \mathrm{~m})$ on the wooden floor of the barn loft to capture fecal pellets throughout the following day while bats were roosting. We checked the roosting colony during the day to verify that the roosting individuals were the target species, which we easily distinguished from other bats in the study area due to its conspicuous ears (Barbour and Davis 1969). We estimate that colony size varied between 20-100 individuals and observed no species other than Rafinesque's Big-Eared Bat at the roost during our study. We removed the tarpaulin the following night after bats had left the roost, arbitrarily collected up to 30 fecal pellets from the tarpaulin, collected fecal pellets individually in $1.5-\mathrm{ml}$ microcentrifuge tubes filled with $100 \%$ ethanol, and placed the pellets in long-term freezer storage $\left(-80^{\circ} \mathrm{C}\right)$ upon return to the laboratory (within 3 days). At no time were fecal pellets allowed to contact any surface other than the plastic tarpaulin or the microcentrifuge tube. We randomly selected 10 fecal pellets from each sampling interval for subsequent dietary analysis. We sampled at biweekly intervals from August to October 2011, yielding a total of 60 fecal pellets for analysis. All methods used for this portion of the study were in accordance with the Institutional 
Animal Care and Use Committees of the University of Kentucky (IACUC No. A3336-01) and the US National Park Service (IACUC No. 2011-30), and followed the guidelines of the American Society of Mammalogists (Sikes et al. 2011) and requirements of state and federal collection permits.

We conducted surveys of nocturnal insects on the same nights as we collected fecal pellets. Rafinesque's Big-Eared Bat is a habitat generalist relative to other Corynorhinus; this species is known to forage within and along the edges of forest canopies, as well as in open field habitats (Lacki and Dodd 2011). As such, our surveys took place across an array of upland and riverine habitats that covered the range of forest-canopy heights at MCNP. Light traps are widely used to survey lepidopteran assemblages in forested environments (Burford et al. 1999, Covell 2005, Dodd et al. 2008) and we employed them in our study. We placed 10-W blacklight traps (Universal Light Trap, Bioquip Products, Gardena, CA) at multiple sites each survey night ( $n \geq 7$ traps/night). We always placed blacklight traps in the immediate vicinity of the roost location ( $\sim 150 \mathrm{~m}$ away) to ensure that sampling occurred within the home range of bats at the roost location. In addition to this fixed survey location, we systematically chose survey transects (without replacement) from land parcels definable as distinct prescribed burn units (Dodd et al. 2013a, b). We positioned blacklight traps at the micro-scale along these transects by the random assignment of the transect start-position and bearing. All blacklight traps were $\geq 100 \mathrm{~m}$ apart and were separated widely enough to ensure no interference between traps (Muirhead-Thomson, 1991). Based on recommendations in Yela and Holyoak (1997), we conducted our surveys on nights with temperatures $\geq 16{ }^{\circ} \mathrm{C}$ at sunset, no precipitation, and low wind-speeds. We suspended blacklight traps $2.5 \mathrm{~m}$ aboveground prior to sunset and operated them throughout the entire night. This deployment method ensured that traps were visible within forest canopies, as well as near ground level, where Rafinesque's Big-Eared Bat is known to forage (Lacki and Dodd 2011). We placed a dichlorvos-based pest strip $(\sim 2 \mathrm{~cm} \times 6 \mathrm{~cm})$ in each blacklight trap to subdue specimens. We collected trap contents the following morning and counted all Lepidoptera. We identified specimens with wingspans $\geq 20 \mathrm{~mm}$ to family level using Covell (2005) and via comparisons with reference collections at the University of Kentucky. We classified specimens with wingspans $<20 \mathrm{~mm}$ as microlepidoptera and did not identify them to family level. We followed Covell (2005) to separate micro- versus macrolepidopteran families. Our classification of noctuiods followed revisions of LaFontaine and Schmidt (2010).

We identified prey remains within fecal pellets both morphologically and molecularly. We dissected pellets microscopically and identified prey remains to the most specific taxon possible (Whitaker 1988). We placed individual fecal pellets in a sterile pour-boat $(4.1 \mathrm{~cm} \times 3.2 \mathrm{~cm} \times 0.8 \mathrm{~cm}$; Fisher Scientific, Pittsburgh, PA), added $100 \%$ ethanol, and used a disposable pestle to tease them apart (Fisher Scientific) for microscopic dissection. We estimated percent volume of prey items in each pellet at the ordinal level to the nearest 5\%, then preserved individual fecal pellets in $\sim 1.5 \mathrm{ml}$ of $95 \%$ ethanol and placed them in freezer storage $\left(-80{ }^{\circ} \mathrm{C}\right)$ for subsequent DNA-based analysis. We used the same pellets for both morphological 
identification and individual DNA extraction. Prior to DNA extraction, we homogenized each fecal pellet for $\sim 1 \mathrm{~min}$ in 2.0 -ml mortar-and-pestle microcentrifuge tubes. We vortexed sample tubes for $\sim 1 \mathrm{~min}$, centrifuged them at $20,000 \times \mathrm{g}$ for 3 min, and discarded the resulting supernatant. We added $1 \mathrm{ml}$ of water to the tubes and vortexed $\sim 1 \mathrm{~min}$, centrifuged at $20,000 \times \mathrm{g}$ for $3 \mathrm{~min}$, and the discarded the supernatant in all sample tubes. We extracted DNA from the samples using a QIAamp DNA Stool Mini Kit (Qiagen Inc., Chatsworth, CA). We followed the manufacturer's instructions for the isolation of DNA from stool for pathogen detection, carrying out lysis with the manufacturer's premixed ASL buffer solution at $70{ }^{\circ} \mathrm{C}$, and conducting all applicable extra centrifugation steps.

We carried out polymerase chain reactions $(\mathrm{PCR}$; total volume $=50 \mathrm{~mL}$ ) for nucleotide sequencing of the cytochrome-c oxidase subunit 1 gene using C1-J1859 and C1-N-2191 primers, resulting in a 333-base amplicon (Simon et al. 1994). The PCR cocktail and cycling conditions and our confirmation of reaction success followed Dodd et al. (2012a). We used BigDye terminator kits (v. 3.1) and the previously mentioned primer set on an ABI3100 sequencer (Applied Biosystems, Foster City, CA) to sequence PCR products (University of Kentucky Advanced Genetic Technologies Center, Lexington, KY) for those reactions that yielded strong PCR bands of expected size. We sequenced reactions bi-directionally to reduce the possibility of chimeric sequences consisting of DNA fragments from multiple prey items (Dodd et al. 2012a); overlapping forward and reverse sequences were edited and assembled using Geneious (v. 6.0.3, Biomatters Ltd., Auckland, New Zealand). To further reduce the possibility of chimeric sequences, we inspected all chromatograms for double peaks and potential sequencing errors. If strong corresponding signals were not present in forward and reverse chromatographs of sequences, we marked the problematic portions as unidentifiable, or discarded the sample if the majority of a sequence was unknown. We generated a single sequence per fecal pellet (Dodd et al. 2012a). As opposed to the high volume of sequences yielded from next-generation sequencing approaches (Bohmann et al. 2011), this approach produced a far more limited assessment of dietary breadth that likely indicated the most abundant prey DNA within the fecal pellets of our focal species (Dodd et al. 2012a).

In December 2012, we inferred prey identities from the results of web-based searches to compare our unknown DNA sequences with the Barcode of Life Data System (BOLD) (Ratnasingham and Hebert 2007). We followed the methods of Clare et al. (2009) to carry out species-level identification of unknown sequences using BOLD and considered matches of $\geq 99 \%$ similarity between our unknown sequence and a single species in the database sufficiently close to warrant species identification. We also made coarser taxonomic identifications of unknown sequences in the absence of species-level matches if there was a $100 \%$ probability of placement within the broader phylogeny indexed by BOLD (and $\geq 98 \%$ similarity; Clare et al. 2011).

We calculated a mean \pm SE wingspan for all lepidopteran genera or species identified in fecal pellets using BOLD. Wingspan values are the standard measurement for the size of Lepidoptera in eastern North America (Covell 2005). We used the 
midpoints of the wingspan ranges provided by Covell (2005) and the Bug Guide database (Iowa State University 2013). We used these midpoint values to generate an unweighted mean $\pm \mathrm{SE}$ of the prey wingspan, with each taxon included once in the calculation. We then compared the mean wingspan of prey identified in this study with the mean wingspan of lepidopteran prey previously reported in the literature (Lacki and Dodd 2011) using a Wilcoxon rank-sum test (SAS Institute 2002). We similarly compared the mean wingspan of prey calculated for Rafinesque's Big-eared Bat in this study with the mean wingspans for Lepidoptera consumed by the Northern Long-Eared Bat (Dodd et al. 2012a) using a Wilcoxon rank-sum test (SAS Institute 2002). Lastly, we assessed patterns of lepidopteran consumption at the family level in relation to the relative occurrence of these prey families, as indexed by our blacklight surveys. We plotted the frequency values to determine if prey consumption followed the general pattern of the lepidopteran community's composition.

\section{Results}

We were able to extract and amplify DNA from 54 pellets (90\% success). Multiple identifications $(n=7)$ came back with a closest-similarity match to the DNA for the Rafinesque's Big-Eared Bat. Beyond these non-target amplifications, nearly all sequences $(98 \%)$ for which high-resolution matches (genus/species) could be made were identified as Lepidoptera, except for a single dipteran outcome (Chironomidae: Chironomus). Of the 21 lepidopteran species identified (Table 1), all were new dietary records for the Rafineque's Big-Eared Bat except Mythimna unipuncta (Armyworm Moth). We archived on the Dryad Digital Repository (doi: $10.5061 /$ dryad.79p7n) sequences with complete genus/species identities. Morphological dissections showed Lepidoptera formed $71.2 \pm 1.7 \%$ (mean \pm SE) of the volume of pellet.

The size of Lepidoptera eaten by Rafinesque's Big-Eared Bat in our study differed from previous reports for the species, and also differed from the size of prey previously documented for the Northern Long-Eared Bat. The mean wingspan of prey detected using DNA-based methods was smaller than our measurements of culled prey-remnants below feeding roosts $(35.9 \pm 1.5 \mathrm{~mm}$ versus $51.2 \pm 2.4 \mathrm{~mm}$, respectively; $\left.\chi^{2}=21.5, \mathrm{df}=1, P \leq 0.01\right)$. Prey consumed by Rafinesque's Big-Eared Bat were larger than prey reported for the Northern Long-Eared Bat (35.9 $\pm 1.5 \mathrm{~mm}$ versus $27.2 \pm 3.6 \mathrm{~mm}$, respectively; $\left.\chi^{2}=11.3 \mathrm{df}=1, P \leq 0.01\right)$.

We captured a total of 6084 Lepidoptera in blacklight traps on the same nights that we collected fecal pellets ( 6 nights, $n=48$ trap-nights, $127 \pm 27$ moths per trapnight). Considering only the macrolepidoptera captured, the most common family was the Erebidae (43\%), followed by the Geometridae $(25 \%)$, Noctuidae $(17 \%)$, Notodontidae (9\%), and other families $(6 \%)$. However, the majority of Lepidoptera $(66 \%)$ possessed wingspans $<20 \mathrm{~mm}$. The most abundant families identified across all Lepidoptera remained the Erebidae, Geometridae, Noctuidae, and Notodontidae (Fig. 1); these same macrolepidopteran families were most heavily consumed by Rafinesque's Big-Eared Bat. We documented reduced consumption of microlepidoptera as well as the largest representatives in the macrolepidoptera 
Table 1. Prey identified for Rafinesque's Big-Eared Bat at Mammoth Cave National Park, KY, using a molecular technique. ${ }^{*}$ denotes prey species previously documented in the diet of Corynorhinus.

\begin{tabular}{|c|c|c|c|}
\hline Order & Family & Genus / Species & Comon name \\
\hline Diptera & Chironomidae & Chironomus sp. & Midge \\
\hline \multirow[t]{21}{*}{ Lepidoptera } & Crambidae & Herpetogramma thestealis (Walker) & Zigzag Herpetogramma Moth \\
\hline & Erebidae & Hypena scabra (Fabricius) & Green Cloverworm Moth \\
\hline & & Palthis angulalis (Hübner) & Dark-spotted Palthis Moth \\
\hline & & Spilosoma virginica (Fabricius) & Virginian Tiger Moth \\
\hline & & Zale lunata (Drury) ${ }^{*}$ & Lunate Zale \\
\hline & Euteliidae & Paectes abrostoloides (Guenée) & Large Paectes Moth \\
\hline & Geometridae & Antepione thisoaria (Guenée) & Variable Antepione \\
\hline & & Melanolophia canadaria (Guenée) ${ }^{*}$ & Canadian Melanolophia Moth \\
\hline & & Nemoria sp. & Emerald moth \\
\hline & Noctuidae & Agrotis gladiaria Morrison & Swordsman Dart Moth \\
\hline & & Amphipyra pyramidoides Guenée* & Copper Underwing Moth \\
\hline & & Anicla infecta (Ochsenheimer) & Green Cutworm Moth \\
\hline & & Athetis tarda (Guenée) & Slowpoke Moth \\
\hline & & Feltia subterranea (Fabricius) & Subterranean Dart Moth \\
\hline & & Graphiphora augur (Fabricius) & Double Dart Moth \\
\hline & & Mythimna unipuncta (Haworth)* & Armyworm Moth \\
\hline & & Nephelodes minians Guenée & Bronzed Cutworm Moth \\
\hline & & Phlogophora periculosa Guenée & Brown Angle Shades Moth \\
\hline & & Spodoptera frugiperda (J.E. Smith) & Fall Armyworm Moth \\
\hline & & Spodoptera ornithogalli (Guenée) & $\begin{array}{l}\text { Yellow-striped Armyworm } \\
\text { Moth }\end{array}$ \\
\hline & Notodontidae & Lochmaeus manteo Doubleday ${ }^{*}$ & $\begin{array}{l}\text { Variable Oakleaf Catarpillar } \\
\text { Moth }\end{array}$ \\
\hline
\end{tabular}

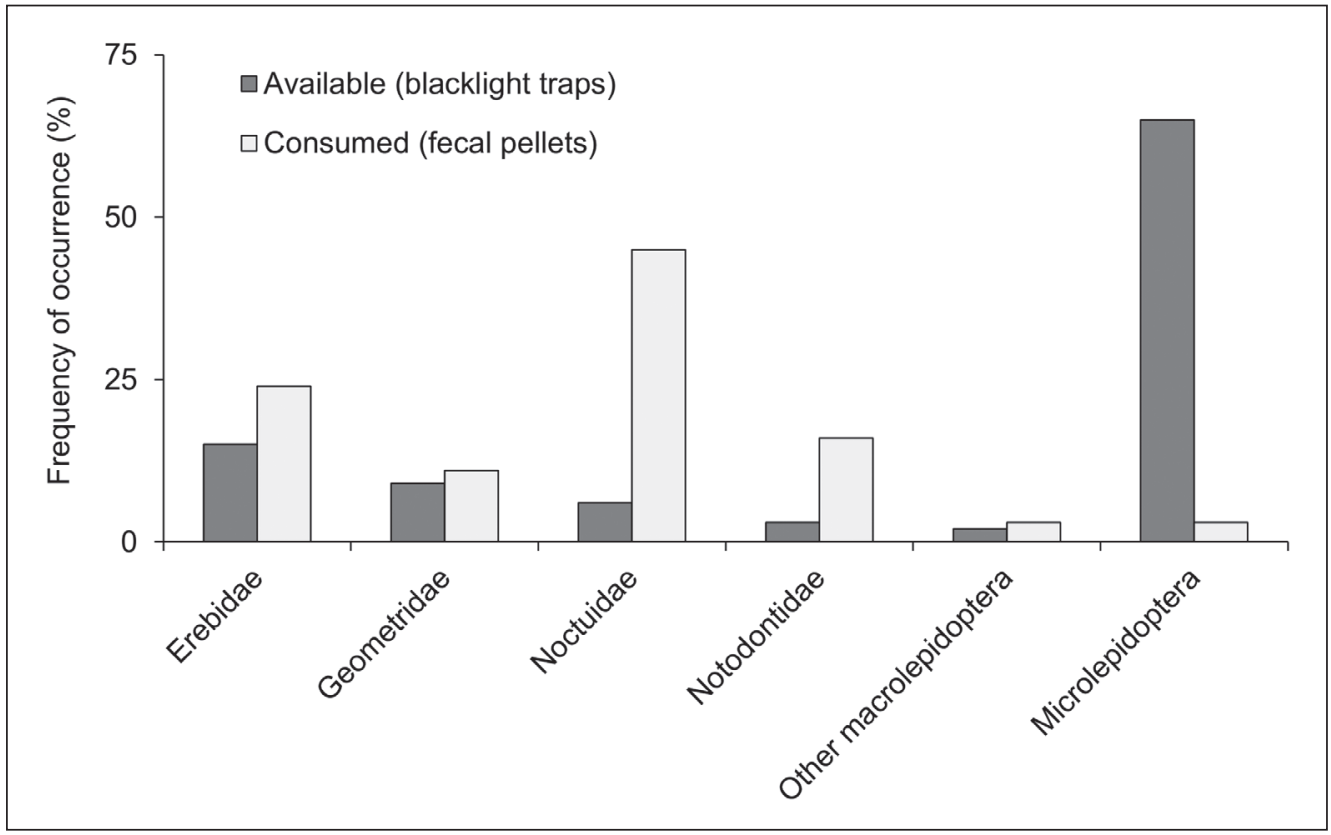

Figure 1. Relative consumption and abundance patterns of Lepidoptera eaten by Rafinesque's Big-Eared Bat at Mammoth Cave National Park, KY. 
(i.e., Saturniidae and Sphingidae).

\section{Discussion}

Our study provides evidence that the Rafinesque's Big-Eared Bat consumes, on average, smaller Lepidoptera than previously documented using traditional methods (Lacki and Dodd 2011). Further, our study expands the breadth of known prey species for the Rafinesque's Big-Eared Bat by more than 66\% (Lacki and Dodd 2011). Given the similarities in size, foraging behaviors, and dietary preferences across Corynorhinus in North America, it is likely that bats in this genus consume a number of Lepidoptera previously unrecorded in studies using traditional methods. These bats presumably consume the smaller prey in their entirety while in flight (Burford and Lacki 1998).

In an assemblage context, these data illuminate the variation inherent in patterns of consumption of Lepidoptera across insectivorous bats in North America. There are 2 primary ensembles of bats in eastern North America that use gleaning as a foraging strategy - the species of Corynorhinus and Myotis (Lacki et al. 2007). Consistent with our hypothesis, the Rafinesque's Big-Eared Bats in our study consumed Lepidoptera on average 33\% larger than species documented for the Northern Long-Eared Bat by Dodd et al. (2012a). Further, 97\% of the Lepidoptera consumed by the Rafinesque's Big-Eared Bat in this study were macrolepidoptera, whereas over half of the prey previously reported for the Northern Long-Eared Bat using the same primers and PCR conditions were microlepidoptera (Dodd et al. 2012a). The mean \pm SE distance between MCNP and sites studied by Dodd et al (2012a) is only $333 \pm 74 \mathrm{~km}$. We suggest the variation in prey size and identity is likely attributable to differences in morphology and echolocation-call characteristics of the 2 predator species. Rafinesque's Big-Eared Bat can be up to $75 \%$ heavier and more than 15\% longer than the Northern Long-Eared Bat (Caceres and Barclay 2000, Jones 1977). The larger size of Rafinesque's Big-Eared Bat likely aids in the capture and handling of larger Lepidoptera, which are thought to be energetically profitable prey items (Razgour et al. 2011). Further, the propensity for plecotine species, including Rafinesque's Big-Eared Bat, to echolocate at lower amplitudes and lower frequencies (Bayless et al. 2011, Lacki and Dodd 2011) could contribute to their ability to detect and handle larger lepidopteran species than the Northern Long-Eared Bat (Barclay and Brigham 1991).

Despite variation in patterns of prey consumption between the Rafinesque's BigEared Bat and Northern Long-Eared Bat, the macrolepidopteran prey selected by the Rafinesque's Big-Eared Bat in our study aligned with observed patterns of abundance for the most common macrolepidopteran families in the study area, as well as across the region (Dodd et al. 2012b, 2013a, 2013b). Prey abundance in our study (127 \pm 27 moths per trap-night) was similar to values reported by Dodd et al. (2012b) for Kentucky, Ohio, and Tennessee $(106 \pm 13,165 \pm 16,62 \pm 8$ moths per trap-night, respectively). In a previous sampling effort in Central Appalachia (Dodd et al. 2012a), the noctuoid families Erebidae and Noctuidae accounted for $60 \%$ of the total community (versus $48 \%$ in the current study). The next most-common 
macrolepidopteran families reported in Dodd et al. (2012a) included the Geometridae $(19 \%)$ and Notodontidae (11\%), mirroring the results in this study $(25 \%$ and $9 \%$, respectively). These results suggest regional similarity between the prey community available to the Rafinesque's Big-Eared Bat in our study and the prey available to the Northern Long-Eared Bat reported in Dodd et al. (2012b).

Lepidopteran families frequently consumed by Rafinesque's Big-Eared Bat included Erebidae, Geometridae, Noctuide, and Notodontidae. Additionally, we noted the absence of larger macrolepidoptera (i.e., Saturniidae and Sphingidae) in the diet of Rafinesque's Big-Eared Bat in our study compared with previous reports in the literature (Lacki and Dodd 2011). Because the primers and PCR conditions used in this study have previously demonstrated amplification of these targets both in bat fecal pellets (Dodd et al. 2012a) and from prey tissue (Dodd 2010), the evidence indicates that neither Saturniidae nor Sphingidae were consistently eaten by the colony of Rafinesque's Big-Eared Bat in our study. While it is possible the approach we used to index prey availability (blacklight traps) might have resulted in a reduced capture of larger-sized Lepidoptera (due to the 3-cm opening to the collection chamber), this standardized trap design still allows for the capture of a wide diversity of Saturniidae and Sphingidae (Burford et al. 1999, Dodd et al. 2011, Ober 2006). If this sampling bias did exist, however, it would strengthen our principal result that Rafinesque's Big-Eared Bats in our study consumed more moderatelysized macrolepidoptera versus what was available on the landscape. We concede that the timing of our study (i.e., during post-lactation when young were volant) does not preclude the possibility of seasonal variance between the prey consumed in our study versus data previously reported for Rafinesque's Big-Eared Bat using traditional techniques (Lacki and Dodd 2011). Also, we only generated a single prey-inference per fecal pellet (Dodd et al. 2012a); thus, we concede that it is likely that some prey species (potentially including Sphingids and Saturniids) were present but undetected in this study.

Our work builds on previous knowledge of prey-consumption patterns for plecotine bats. Prey species consumed by the Rafinesque's Big-Eared Bat in this study align with the size of prey reported for the Mountain Long-Eared Bat (37.6 \pm 1.5 $\mathrm{mm}$; Alberdi et al. 2012). Additionally, the family-level and broader classifications of prey taxa that we documented are similar to those reported for Mountain LongEared Bat, Brown Long-Eared Bat, and Gray Long-Eared Bat (Alberdi et al. 2012, Razgour et al. 2011); patterns in consumption for these bat species demonstrate a general absence of microlepidopteran prey. Data from this and other DNA-based investigations of the food habits of predatory bats continue to offer an opportunity to test hypotheses relevant to behavior, foraging, and phylogeny.

\section{Acknowledgments}

We thank T. Culbertson and J. Winters for assistance with this study. We thank M. Dickinson, N. Skowronski, S. Thomas, and R. Toomey for their help and suggestions. This investigation is connected with a project of the Kentucky Agricultural Experiment Station (KAES No. 13-09-116) and is published with the approval of the director. 
Alberdi, A., I. Garing, O. Aizpurua, and J. Aihartza. 2012. The foraging ecology of the Mountain Long-eared Bat Plecotus macrobullaris revealed with DNA mini-barcodes. PLoS ONE 7:e35692.

Barbour, R.W., and W.H. Davis. Bats of America. University Press of Kentucky, Lexington, KY. 286 pp.

Barclay, R.M.R., and R.M. Brigham. 1991. Prey detection, dietary-niche breadth, and body size in bats: Why are aerial insectivorous bats so small? American Naturalist 137:693-703.

Bat Conservation International and the Southeastern Bat Diversity Network. 2013. A conservation strategy for Rafinesque's Big-Eared Bat (Corynorhinus rafinesquii) and Southeastern Myotis (Myotis austroriparius). Bat Conservation International, Austin, TX. $101 \mathrm{pp}$.

Bayless, M.L., M.K. Clark, R.S. Stark, B.S. Douglas, and S.M. Ginger. 2011. Distribution and status of eastern big-eared bats (Corynorhinus spp.). Pp. 13-25, In S.C. Loeb, M.J. Lacki, and D.A. Miller (Eds.). Conservation and Management of Big-eared Bats: A Symposium. US Department of Agriculture, Forest Service, Southern Research Station, Asheville, NC. v +157 pp.

Bogdanowicz, W., M.B. Fenton, and K. Daleszcyk. 1998. The relationships between echolocation calls, morphology, and diet in insectivorous bats. Journal of Zoology 247:381-393.

Bohmann, K., A. Monadjem, C.L. Noer, M. Rasmussen, M.R.K. Zeale, E. Clare, G. Jones, E. Willerslev, and M.T.P. Gilbert. 2011. Molecular diet-analysis of two African Freetailed Bats (Molossidae) using high-throughput sequencing. PLoS ONE 6: e21441.

Braun, E.L. 1950. Deciduous Forests of Eastern North America. Blackstone Company, Philadelphia, PA. 596 pp.

Burford, L.S., and M.J. Lacki. 1998. Moths consumed by Corynorhinus townsendii virginianus in eastern Kentucky. American Midland Naturalist 139:141-146.

Burford, L.S., M.J. Lacki, and C.V. Covell Jr. 1999. Occurrence of moths among habitats in a mixed mesophytic forest: Implications for management of forest bats. Forest Science 45:323-332.

Caceres, M.C., and R.M.R. Barclay. 2000. Myotis septentrionalis. Mammalian Species 634:1-4.

Clare, E.L., E.E. Fraser, H.E. Braid, M.B. Fenton, and P.D.N. Hebert. 2009. Species on the menu of a generalist predator, the Eastern Red Bat (Lasiurus borealis): Using a molecular approach to detect arthropod prey. Molecular Ecology 18:2532-2542.

Clare, E.L., B.R. Barber, B.W. Sweeney, and P.D.N. Hebert. 2011. Eating local: Influences of habitat on diet of Little Brown Bats (Myotis lucifugus). Molecular Ecology 20:1772-1780.

Covell, Jr., C.V. 2005. A Field Guide to Moths of Eastern North America: Special Publication Number 12. Virginia Museum of Natural History, Martinsville, VA. xxii +496 pp.

Dodd, L.E. 2010. Forest disturbance affects insect prey and the activity of bats in deciduous forests. Ph.D. Dissertation, University of Kentucky, Lexington, KY. $\mathrm{x}+156$ pp.

Dodd, L.E., M.J. Lacki, and L.K. Rieske. 2008. Variation in moth occurrence and the implications for foraging habitat of the Ozark Big-Eared Bat. Forest Ecology and Management 255:3866-3872.

Dodd, L.E., M.J. Lacki, and L.K. Rieske. 2011. Habitat associations of Lepidoptera in the Ozark Mountains of Arkansas. Journal of the Kansas Entomological Society 84: 271-284.

Dodd, L.E., E.G. Chapman, J.D. Harwood, M.J. Lacki, and L.K. Rieske. 2012a. Identifica- 
tion of prey of Myotis septentrionalis using DNA-based techniques. Journal of Mammalogy 93:1119-1128.

Dodd, L.E., M.J. Lacki, E.R. Britzke, D.A. Buehler, P.D. Keyser, J.L. Larkin, A.D. Rodewald, T.B. Wigley, P.B. Wood, and L.K. Rieske. 2012b. Forest structure affects trophic linkages: How silvicultural disturbance impacts bats and their insect prey. Forest Ecology and Management 267:262-270.

Dodd, L.E., Z. Cornett, A. Smith, and L.K. Rieske. 2013a. Variation in lepidopteran occurrence in hemlock-dominated and deciduous-dominated forests of Central Appalachia. Great Lakes Entomologist 46:1-12.

Dodd, L.E., N.S. Skowronski, M.B. Dickinson, M.J. Lacki, and L.K. Rieske. 2013b. Using LiDAR to link forest-canopy structure with bat activity and insect occurrence: Preliminary findings. Pp. 50-57, In S.R. Trimboli (Ed.). Proceedings of Mammoth Cave National Park's $10^{\text {th }}$ Research Symposium. US National Park Service, Mammoth Cave National Park, Mammoth Cave, KY. 207 pp.

Faure, P.A., J.H. Fullard, and J.H. Dawson. 1993. The gleaning attacks of the Northern Long-Eared Bat, Myotis septentrionalis, are relatively inaudible to moths. Journal of Experimental Biology 178:173-189.

Freeman, P.W. 1981. Correspondence of food habits and morphology in insectivorous bats. Journal of Mammalogy 62:166-173.

Iowa State University. 2013. Bug Guide. Available online at www.bugguide.net. Accessed April 2013.

Johnson, J.S., M.J. Lacki, S.C. Thomas, and J.F. Grider. 2012. Frequent arousals from winter torpor in Rafinesque's Big-eared Bat (Corynorhinus rafinesquii). PLoS ONE 7:e49754.

Jones, C. 1977. Plecotus rafinesquii. Mammalian Species 69:1-4.

Lacki, M.J., and L.E. Dodd. 2011. Diet and foraging behavior of Corynorhinus in eastern North America. Pp. 39-52, In S.C. Loeb, M.J. Lacki, and D.A. Miller (Eds.). Conservation and management of big-eared bats: A symposium. US Department of Agriculture, Forest Service, Southern Research Station, Asheville, NC. v +157 pp.

Lacki, M.J., S.K. Amelon, and M.D. Baker. 2007. Foraging ecology of forest bats. Pp. 83-128, In M.J. Lacki, J.P. Hayes, and A. Kurta (Eds.). Bats in Forests: Conservation and Management. John Hopkins University Press, Baltimore, MD. xvi + 329 pp.

LaFontaine, J.D., and B.C. Schmidt. 2010. Annotated checklist of the Noctuoidea (Insecta, Lepidoptera) of North America north of Mexico. Zookeys 40:1-239.

Muirhead-Thomson, R.C. 1991. Trap Responses of Flying Insects. Academic Press, London, UK. 304 pp.

Ober, H.K. 2006. Functional relationships among vegetation, nocturnal insects, and bats in riparian areas of the Oregon Coast Range. Ph.D. Dissertation. Oregon State University, Corvallis, OR. xiv +224 pp.

Ratnasingham, S., and P.D.N. Hebert. 2007. BOLD: The Barcode of Life Data System (http://www.barcodinglife.org). Molecular Ecology Notes 7: 355-364. doi: 10.1111/j.1471-8286.2007.01678.x

Razgour, O., E.L. Clare, M.R.K. Zeale, J. Hammer, I.B. Schnell, M. Rasmussen, T.P. Gilbert, and G. Jones. 2011. High-throughput sequencing offers insight into mechanisms of resource partitioning in cryptic species. Ecology and Evolution. 1:556-570.

Sample, B.E., and R.C. Whitmore. 1993. Food habits of the endangered Virginia Big-Eared Bat in West Virginia. Journal of Mammalogy 74:428-435.

SAS Institute, Inc. 2002. SAS version 9. Cary, NC.

Sikes, R.S., W.L. Gannon, and the Animal Care and Use Committee of the American Soci- 
ety of Mammalogists. 2011. Guidelines of the American Society of Mammalogists for the use of wild mammals in research. Journal of Mammalogy 92:235-253.

Simon, C., F. Frati, A. Beckenbach, B. Crespi, L. Hong, and P. Flook. 1994. Evolution, weighting, and phylogenetic utility of mitochondrial-gene sequences and a compilation of conserved polymerase chain-reaction primers. Annals of the Entomological Society of America 87:651-701.

Whitaker, J.O., Jr. 1988. Food-habits analysis of insectivorous bats. Pp. 171-189, In T.H. Kunz (Ed.). Ecological and Behavioral Methods for the Study of Bats. Smithsonian Institution Press, Washington DC. 533 pp.

Woods, A.J., J.M. Omernik, W.H. Martin, G.J. Pond, W.M. Andrews, S.M. Call, J.A. Comstock, and D.D. Taylor. 2002. Ecoregions of Kentucky (color poster with map, descriptive text, summary tables, and photographs; map scale 1:1,000,000). WO-1-02. US Geological Survey, Reston, VA.

Yela, J.L., and M. Holyoak. 1997. Effects of moonlight and meteorological factors on light and bait-trap catches of noctuid moths. Environmental Entomology 2:1283-1290. 